Review

\title{
The efficacy of Schwann cell transplantation on motor function recovery after spinal cord injuries in animal models: A systematic review and meta-analysis
}

\author{
Mostafa Hosseini, Ph.D ${ }^{\mathrm{a}, \mathrm{b}}$, Mahmoud Yousefifard, Ph.D ${ }^{\mathrm{c}, *}$, Masoud Baikpour, MD ${ }^{\mathrm{d}}$, \\ Vafa Rahimi-Movaghar, MD ${ }^{\mathrm{a}}$, Farinaz Nasirinezhad, Ph. ${ }^{\mathrm{c}}$, Somaye Younesian, MD $^{\mathrm{e}}$, \\ Saeed Safari, MD ${ }^{\mathrm{f}}$, Parisa Ghelichkhani, $\mathrm{MSc}^{\mathrm{g}}$, Ali Moghadas Jafari, $\mathrm{MD}^{\mathrm{h}}$ \\ a Sina Trauma and Surgery Research Center, Tehran University of Medical Sciences, Tehran, Iran \\ ${ }^{\mathrm{b}}$ Department of Epidemiology and Biostatistics, School of Public Health, Tehran University of Medical Sciences, Tehran, Iran \\ ${ }^{\mathrm{c}}$ Physiology Research Center and Department of Physiology, Faculty of Medicine, Iran University of Medical Sciences, Tehran, Iran \\ ${ }^{\mathrm{d}}$ Department of Medicine, School of Medicine, Tehran University of Medical Sciences, Tehran, Iran \\ e Department of Emergency Medicine, Qom University of Medical Sciences, Qom, Iran \\ ${ }^{\mathrm{f}}$ Department of Emergency Medicine, Shohadaye Tajrish Hospital, Shahid Beheshti University of Medical Sciences, Tehran, Iran \\ ${ }^{g}$ Department of Intensive Care Nursing, School of Nursing and Midwifery, Tehran University of Medical Sciences, Tehran, Iran \\ ${ }^{\mathrm{h}}$ Department of Emergency Medicine, School of Medicine, Bushehr University of Medical Sciences, Bushehr, Iran
}

\section{A R T I C L E I N F O}

\section{Article history:}

Received 10 May 2016

Received in revised form 9 July 2016

Accepted 4 September 2016

Available online 5 September 2016

\section{Keywords:}

Spinal cord injuries

Regeneration

Motor function recovery

Schwann cells

Meta-analysis

\begin{abstract}
A B S T R A C T
Aim: This article aimed to assess the efficacy of Schwann cell transplantation on motor function recovery in animal model of spinal cord injuries via meta-analysis.

Methods: An extended search was carried out in the electronic databases of Medline (via PubMed), EMBASE (via OvidSP), CENTRAL, SCOPUS, Web of Science (BIOSIS), and ProQuest. Finally, 41 eligible studies conducted on 1046 animals including 517 control animals and 529 transplanted animals were included in the meta-analysis. Pooled standardized mean difference (SMD) and odds ratio (OR) with 95\% confidence interval $(95 \% \mathrm{CI})$ were reported.

Results: The findings showed that treatment with Schwann cells leads to a modest motor function recovery after spinal cord injury (SMD $=0.85 ; 95 \% \mathrm{CI}$ : 0.63-1.07; $\mathrm{p}<0.001)$. Transplantation of these cells in acute phase of the injury (immediately after the injury) ( $\mathrm{OR}=4.30 ; 95 \% \mathrm{CI}: 1.53-12.05 ; \mathrm{p}=0.007$ ), application of mesenchymal/skin-derived precursors ( $\mathrm{OR}=2.34 ; 95 \% \mathrm{CI}: 1.28-4.29 ; \mathrm{p}=0.008$ ), and cells with human sources are associated with an increase in efficacy of Schwann cells (OR $=10.96 ; 95 \% \mathrm{CI}$ : 1.49-80.77; $p=0.02$ ). Finally, it seems that the efficacy of Schwann cells in mice is significantly lower than rats $(\mathrm{OR}=0.03 ; 95 \% \mathrm{CI}: 0.003-0.41 ; \mathrm{p}=0.009)$.

Conclusion: Transplantation of Schwann cells can moderately improve motor function recovery. It seems that inter-species differences might exist regarding the efficacy of this cells. Therefore, this should be taken into account when using Schwann cells in clinical trials regarding spinal cord injuries.
\end{abstract}

(c) 2016 Elsevier B.V. All rights reserved.

\section{Contents}

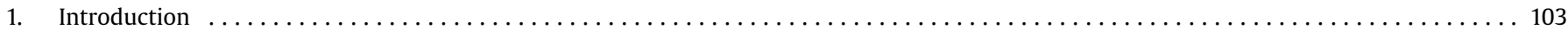

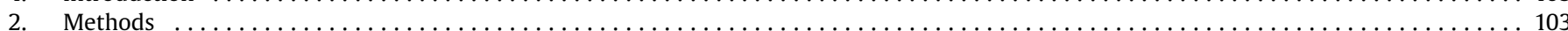

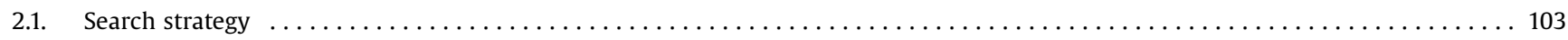

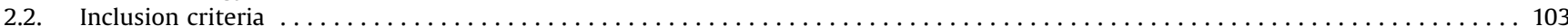

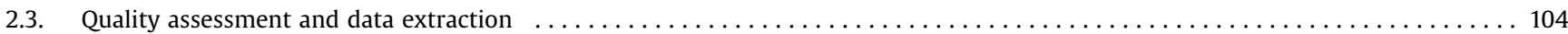

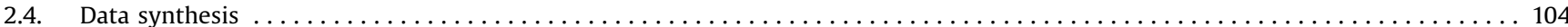

\footnotetext{
* Corresponding author at: Department of Physiology, School of Medicine,

Hemmat Highway, Tehran, P.O Box: 14665-354, Iran.

E-mail address: yousefifard20@gmail.com (M. Yousefifard).
} 


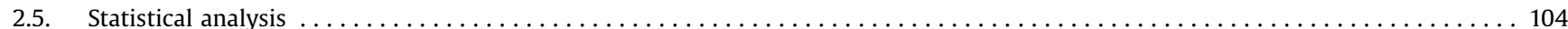

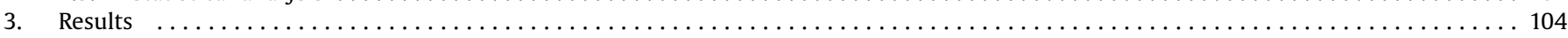

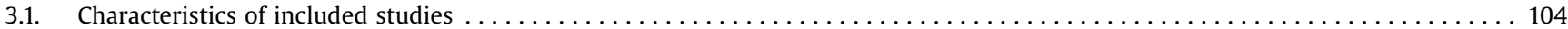

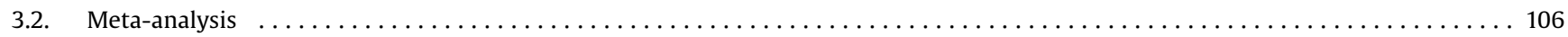

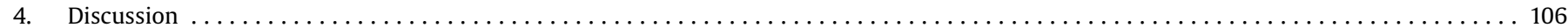

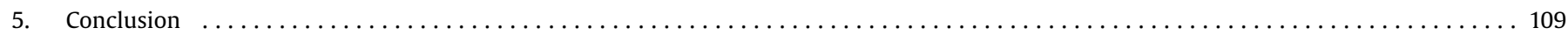

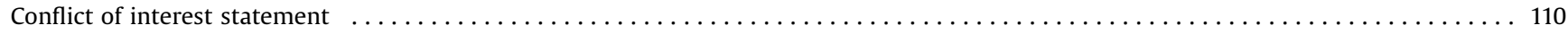

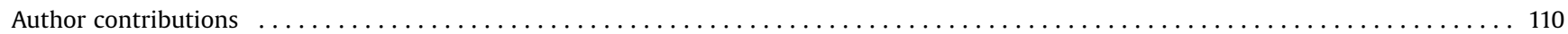

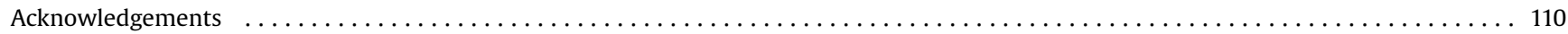

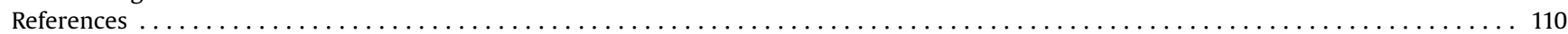

\section{Introduction}

In recent years, cell therapy has been considered as a promising method in treatment of spinal cord injuries (Hosseini et al., 2015). Although multiple sources have been proposed for the transplanted cells, Schwann cells have always been regarded as one of the best candidates for this treatment (Kanno et al., 2014; Pearse et al., 2004a, 2004b; Takami et al., 2002). Schwann cells are responsible for neural protection and myelination in peripheral nervous system and normally they are not found in central nervous system. After injury, these cells migrate to the site of the lesion through the dorsal root and help the recovery to some extent. Studies suggest that application of Schwann cells can lead to a better recovery of sensory and motor function after spinal cord injuries (Kanno et al., 2014; Takami et al., 2002). However, a considerable number of surveys have yielded contradictory results (Barakat et al., 2005; Maldonado et al., 2006; Pearse et al., 2004b).

Recently, two meta-analyses, including data from 14 animal studies, proposed that transplantation of Schwann cells can significantly improve recovery of motor function in rats after spinal cord injuries (Lu et al., 2015; Yang et al., 2015a). However, presence of some limitation such as performing inefficient search, using unrelated keywords, and being subject to publication bias warrants the need for a redo of this meta-analysis. In this regard the present study aimed to re-evaluate the efficacy of Schwann cells in motor function recovery after spinal cord injury through a meta-analytic systematic review.

\section{Methods}

\subsection{Search strategy}

In this study, an extended search was carried out in the databases of Medline (via PubMed), EMBASE (via OvidSP), CENTRAL, SCOPUS, Web of Science (BIOSIS), and ProQuest, from 1 June 1946 until the end of September 2015. Search strategy was designed based on combining keywords related to "Schwann-like" and "Schwann cells" with terms related to "spinal cord injury" (Table 1). The keywords were selected based on three methods: a) from the Mesh and EMTREE terms; b) based on manual search in the titles and abstracts of the related articles; and c) through consultation with two specialists.

Findings from PubMed Central were also included when the PubMed database was searched. Moreover, non-indexed reports were also searched in Google search engine and Google scholar. The authors of the related articles were also asked to provide any unpublished data, information that is not registered or unpublished dissertations, if possible. The ProQuest database was also precisely searched for related theses. In cases where data were not available online, the corresponding author of article was contacted. A reminder was also sent to the author after one week of no response. If no answer was received, the co-authors were contacted through social networks such as ResearchGate and LinkedIn.

In order to find further studies and unpublished data, handsearch was carried out in the bibliography of relevant studies which yielded two more articles. Furthermore, hand-searching of journals was also performed. The articles were imported into EndNote X7 software and then a list of highly focused journals was created which included journals that had published the highest number of articles in the fields of stem cell therapy, neuroscience and spine. All the issues of these journals were manually searched and three more articles were found for inclusion in the metaanalysis.

\subsection{Inclusion criteria}

In the present study controlled animal surveys were included, in which the efficacy of Schwann cells in recovery of motor function after spinal cord injury was evaluated in rat and mice. Studies in which the cells were changed or modified in order to increase their efficacy were excluded. Genetic modification for cell labeling was not considered as an exclusion criterion. A follow up of less than 4 weeks was another exclusion criterion since the minimum duration of time needed for the cell therapy to take effect is three to four weeks. Surveys lacking control groups (sham, saline treated, or vehicle treated groups) were also excluded. Since the authors had aimed to evaluate the net effect of Schwann cells in recovery of motor function, the studies that had used cotreatments with these cells were also left out.

Table 1

Keywords used for search in databases of MEDLINE and EMBASE.

\begin{tabular}{|c|c|}
\hline Database & Search terms \\
\hline $\begin{array}{l}\text { Medline } \\
\text { (PubMed) }\end{array}$ & $\begin{array}{l}\text { (Schwann Cells[mh] OR Schwann Cell*[mh] OR Schwannomas[tiab] OR Schwann*[tiab] OR Schwann-Like Cell*[tiab] OR SCs[tiab] OR SCs[tiab]) AND } \\
\text { ("Spinal cord injuries"[MeSH] OR Spinal cord contusion[tiab] OR Spinal cord transection[tiab] OR Injured spinal cord[tiab] OR Spinal Cord Traum*[tiab] } \\
\text { OR Spinal cord Hemisection[tiab] OR Spinal compression[tiab] OR Traumatic Myelopath*[tiab] OR Spinal Cord Laceratio*[tiab] OR Post-Traumatic } \\
\text { Myelopath*[tiab]) }\end{array}$ \\
\hline $\begin{array}{l}\text { EMBASE } \\
\text { (OvidSP) }\end{array}$ & $\begin{array}{l}\text { exp Schwann Cells/OR (Schwann Cell\$ OR Schwannomas OR Schwann\$ OR Schwann-Like Cell\$ OR SCs).ti,ab. AND exp Spinal cord injuries/OR (Spinal } \\
\text { cord contusion OR Spinal cord transection OR Injured spinal cord OR Spinal Cord Traum\$ OR Spinal cord Hemisection OR Spinal compression OR Spinal } \\
\text { Cord Laceratio\$).ti,ab. }\end{array}$ \\
\hline
\end{tabular}




\subsection{Quality assessment and data extraction}

The findings of our searches were combined and the duplicate articles were removed via EndNote (version X7, Thomson Reuters, 2011). Two authors (M.Y and S.S) independently evaluated the titles and abstracts of the articles and screened potentially eligible studies. Subsequently, full-texts of these articles were studied and the ones that met the inclusion criteria were selected. Data were recorded in a checklist designed based on the guidelines of PRISMA statement (Moher et al., 2009). Extracted data included a) information related to characteristics of the animals, b) method of spinal cord injury induction, c) cell therapy protocol, d) follow up duration, e) evaluated outcome, and f) possible biases. Two reviewers assessed methodology of potentially relevant articles (93\% agreement). In cases of disagreement between the two reviewers, a third person (A.MJ) evaluated the articles and the problem was solved through discussion with the two authors. Quality assessment of the studies was performed via the method suggested by Antonic et al. (Antonic et al., 2013).

\subsection{Data synthesis}

The target outcome in the present study was motor function recovery. Data were recorded as means and standard errors. Since the results were given as charts in most of these surveys, the method of data extraction from charts, proposed by Sistrom and Mergo, (Sistrom and Mergo, 2000) was used. The last evaluation of motor function recovery was included in the study. In cases where repetitive results were given, the study with the largest sample size and the longest follow up duration was included.

\subsection{Statistical analysis}

Data were summarized into mean and standard deviation figures and were entered into STATA 11.0 software. For each individual comparison, a standardized mean difference (SMD) was calculated with a confidence interval of 95\% (95\% CI), based on Hedges' g. Then a pooled effect size was presented. Evaluation of publication bias was done through drawing a funnel plot using the Egger's and Begg's tests (Egger et al., 1997). Heterogeneity between the studies was assessed via Chi-Squared and $\mathrm{I}^{2}$ tests and a $\mathrm{p}$ value of less than 0.1 along with an $\mathrm{I}^{2}$ greater than $50 \%$ were considered as presence of heterogeneity. Fixed effect model was utilized if the studies were homogenous, and if not, subgroup analysis was performed to find the source of heterogeneity. Random effect model was fitted for cases with no apparent source of heterogeneity. Subgroup analysis was carried out based on animals' gender, recipient species, injury model, location of injury, severity of injury, stem cells derivation origin, intervention phase (acute, subacute, chronic), graft type (allogeneic, xenogeneic), number of transplanted cells, donor species, use of co-treatment, antibiotic and immunosuppressive agents use, and blinding of the observer. Finally a meta-regression was performed in order to find the factors that influence the efficacy of Schwann cells in motor function recovery and odds ratio (OR) with a confidence interval of $95 \%$ were present. A p value of less than 0.05 was considered as statistically significant in all analyses.

\section{Results}

\subsection{Characteristics of included studies}

Search in electronic databases yielded 3409 non-repetitive records, from which 132 potentially eligible studies were identified and eventually 41 studies were included in the meta-analysis (Ban et al., 2011; Barakat et al., 2005; Barbour et al., 2013; Bunge, 2008; Firouzi et al., 2006; Flora et al., 2013; Garcia-Alias et al., 2004; Ghosh et al., 2012; Hill et al., 2012; Hu et al., 2013; Joghataei et al., 2010; Kamada et al., 2011, 2005; Kanno et al., 2014; Lavdas et al., 2010; Li et al., 2012; Madigan et al., 2014; Maldonado et al., 2006; Marcol et al., 2015; Moradi et al., 2012; Niapour et al., 2012; Papastefanaki et al., 2007; Pearse et al., 2004a, 2004b, 2007; Peng

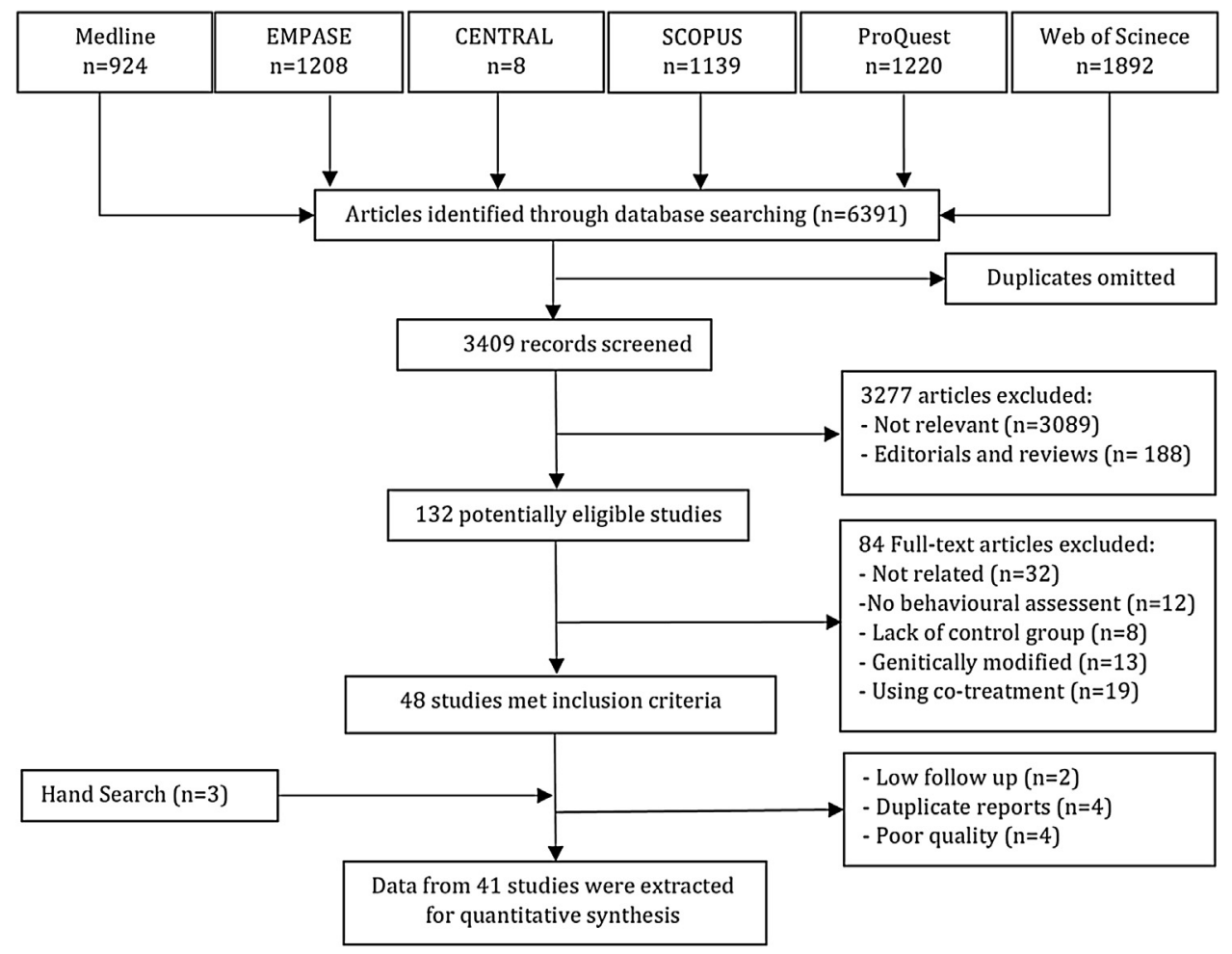

Fig. 1. Flowchart of including studies in the meta-analysis. 
Table 2

Characteristics of included studies.

\begin{tabular}{|c|c|c|c|c|c|}
\hline Author, Year & $\begin{array}{l}\text { Gender/Species/ } \\
\text { Weight }\end{array}$ & Model/Location of injury ${ }^{a} /$ Severity & $\begin{array}{l}\text { Cell source/Donor/Graft/Dose/Type/ } \\
\text { Intervention time (day) }\end{array}$ & $\begin{array}{l}\text { Immunosuppressive/ } \\
\text { Antibiotic/Blinding }\end{array}$ & $\begin{array}{l}\text { Follow up } \\
\text { (day) }\end{array}$ \\
\hline Ban et al. (2011) & Female/Rat/250-250 & Contusion/T10/Moderate & Sciatic nerve/Rat/IS/3 × $10^{6} /$ Allogeneic/7 & Yes/Yes/Yes & 77 \\
\hline $\begin{array}{l}\text { Barakat et al. } \\
\text { (2005) }\end{array}$ & Female/Rat/180-200 & Contusion/T9/Moderate & Sciatic nerve/Rat/IS/2 $\times 10^{6} /$ Allogeneic/56 & No/Yes/No & 56 \\
\hline $\begin{array}{l}\text { Barbour et al. } \\
\text { (2013) }\end{array}$ & Female/Rat/180-200 & Contusion/T10/Moderate & Sciatic nerve/Rat/IS/5 $\times 10^{5} /$ Allogeneic/14 & No/Yes/Yes & 126 \\
\hline Bunge (2008) & Female/Rat/250-300 & Compression/T9-T11/Moderate & $\begin{array}{l}\text { Subcutaneous skin cells/Rat/IS/5 } \times 10^{5} / \\
\text { Allogeneic/9 }\end{array}$ & Yes/Yes/Yes & 56 \\
\hline $\begin{array}{l}\text { Firouzi et al. } \\
\text { (2006) }\end{array}$ & Female/Rat/100-140 & Compression/T10/Moderate & Sciatic nerve/Rat/IS/5 $\times 10^{4} /$ Allogeneic/7 & No/Yes/Yes & 70 \\
\hline Flora et al. (2013) & Female/Rat/180-200 & Contusion/T9/Moderate & Sciatic nerve/Rat/IS/2 × $10^{6} /$ Allogeneic/7 & No/Yes/Yes & 84 \\
\hline $\begin{array}{l}\text { Garcia-Alias et al. } \\
(2004)\end{array}$ & Female/Rat/200-250 & Photochemical/T8/Moderate & Sciatic nerve/Rat/IS/1.8 $\times 10^{5} /$ Allogeneic/ 1 & No/No/Yes & 90 \\
\hline Ghosh et al. (2012) & Female/Rat/180-200 & Contusion/T9/Moderate & Sciatic nerve/Rat/IS/2 $\times 10^{6} /$ Allogeneic/7 & $\mathrm{No} / \mathrm{No} / \mathrm{Yes}$ & 56 \\
\hline Hill et al. (2012) & Female/Rat/190-196 & Contusion/T9/Moderate & Sciatic nerve/Rat/IS/2 × $10^{6} /$ Allogeneic/7 & No/Yes/Yes & 70 \\
\hline Hu et al. (2013) & Female/Rat/160-180 & Contusion/T10/Moderate & Sciatic nerve/Rat/IS/4 $\times 10^{5} /$ Allogeneic/9 & Yes/No/Yes & 42 \\
\hline $\begin{array}{l}\text { Joghataei et al. } \\
\text { (2010) }\end{array}$ & Male/Rat/250-300 & Contusion/T8-T9/Moderate & Sciatic nerve/Rat/IS/3 $\times 10^{5} /$ Allogeneic/7 & No/Yes/No & 56 \\
\hline $\begin{array}{l}\text { Kamada et al. } \\
(2005)\end{array}$ & Male/Rat/200-200 & Transection/T7-T8/Severe & MSC/Rat/IS/2 × $10^{6} /$ Allogeneic/1 & Yes/Yes/No & 42 \\
\hline $\begin{array}{l}\text { Kamada et al. } \\
\text { (2011) }\end{array}$ & Male/Rat/200-200 & Contusion/T9/Moderate & MSC/human/IS/2 $\times 10^{6} /$ Xenogeneic/7 & Yes/Yes/No & 35 \\
\hline Kanno et al. (2014) & Female/Rat/160-180 & Contusion/T8/Moderate & Sciatic nerve/Rat/IS/2 × $10^{6} /$ Allogeneic/7 & No/Yes/Yes & 84 \\
\hline Lavdas et al. (2010) & Female/Mice/20-25 & Compression/T7-T9/Moderate & Sciatic nerve/Mice/IS/ $1 \times 10^{5} /$ Allogeneic/1 & No/No/Yes & 28 \\
\hline Li et al. (2012) & Male/Rat/200-250 & Contusion/T10/Moderate & Sciatic nerve/Rat/IS/9 $\times 10^{4} /$ Allogeneic/7 & No/Yes/Yes & 36 \\
\hline $\begin{array}{l}\text { Madigan et al. } \\
\text { (2014) }\end{array}$ & Female/Rat/230-250 & Transection/T9/Severe & $\begin{array}{l}\text { Sciatic nerve/Rat/IS/2.38 } \times 10^{5} / \text { Allogeneic/ } \\
1\end{array}$ & No/Yes/Yes & 28 \\
\hline $\begin{array}{l}\text { Maldonado et al. } \\
\text { (2006) }\end{array}$ & Female/Rat/180-220 & Contusion/T10-T11/Moderate & Sciatic nerve/Rat/IS/5 × $10^{5} /$ Allogeneic/5 & Yes/No/Yes & 60 \\
\hline Marcol et al. (2015) & Male/Rat/300-300 & Compression/T10/Moderate & Sciatic nerve/Rat/IT/9 $\times 10^{5} /$ Allogeneic/ 1 & No/No/Yes & 84 \\
\hline $\begin{array}{l}\text { Moradi et al. } \\
\quad(2012)\end{array}$ & Male/Rat/250-280 & Contusion/T10/Moderate & $\begin{array}{l}\text { Sciatic nerve/human/IS } / 5 \times 10^{5} / \\
\text { Xenogeneic/7 }\end{array}$ & Yes/Yes/Yes & 56 \\
\hline $\begin{array}{l}\text { Niapour et al. } \\
\text { (2012) }\end{array}$ & Male/Rat/250-300 & Contusion/T9-T10/Moderate & MSC/human/IS/5 × $10^{5} /$ Allogeneic/7 & Yes/Yes/Yes & 62 \\
\hline $\begin{array}{l}\text { Papastefanaki et al. } \\
\text { (2007) }\end{array}$ & Female/Mice/20-25 & Compression/T7-T9/Moderate & Sciatic nerve/mice/IS/5 × $10^{5} /$ Allogeneic/ 1 & No/No/Yes & 28 \\
\hline $\begin{array}{l}\text { Pearse et al. } \\
\text { (2004a) }\end{array}$ & Female/Rat/160-180 & Contusion/T9/Moderate & Sciatic nerve/Rat/IS/2 $\times 10^{6} /$ Allogeneic/7 & No/Yes/Yes & 84 \\
\hline $\begin{array}{l}\text { Pearse et al. } \\
\text { (2004b) }\end{array}$ & Female/Rat/160-180 & Contusion/T9/Moderate & Sciatic nerve/Rat/IS/2 $\times 10^{6} /$ Allogeneic/7 & No/Yes/Yes & 56 \\
\hline Pearse et al. (2007) & Female/Rat/180-200 & Contusion/T9/Moderate & Sciatic nerve/Rat/IS/2 × $10^{6} /$ Allogeneic/7 & No/Yes/Yes & 63 \\
\hline Peng et al. (2015) & Female/Rat/200-250 & Contusion/T8-T9/Moderate & Sciatic nerve/Rat/IV/3 $\times 10^{6} /$ Allogeneic/1 & No/Yes/Yes & 56 \\
\hline $\begin{array}{l}\text { Pourheydar et al. } \\
\text { (2012) }\end{array}$ & Female/Rat/250-300 & Contusion/T8/Moderate & Sciatic nerve/Rat/IS/3 × $10^{5} /$ Allogeneic/7 & No/Yes/Yes & 56 \\
\hline Schaal et al. (2007) & Female/Rat/180-200 & Contusion/C5/Moderate & Sciatic nerve/Rat/IS/2 $\times 10^{6} /$ Allogeneic/7 & No/Yes/Yes & 49 \\
\hline Sharp et al. (2012) & Female/Rat/160-180 & Contusion/T9/Moderate & Sciatic nerve/Rat/IS/2 $\times 10^{6} /$ Allogeneic/7 & No/Yes/Yes & 63 \\
\hline $\begin{array}{l}\text { Someya et al. } \\
\text { (2008) }\end{array}$ & Male/Rat/225-250 & Contusion/T8-T9/Moderate & Sciatic nerve/Rat/IS/5 × $10^{5} /$ Allogeneic/7 & Yes/Yes/Yes & 35 \\
\hline $\begin{array}{l}\text { Someya et al. } \\
\text { (2008) }\end{array}$ & Male/Rat/225-250 & Contusion/T8-T9/Moderate & MSC/Rat/IS/5 × 105 /Allogeneic/7 & Yes/Yes/Yes & 35 \\
\hline Sparling et al. & Male/Rat/300-500 & $\begin{array}{l}\text { Dorsolateral funiculus lesioning/ } \\
\text { C4-C5/Moderate }\end{array}$ & $\begin{array}{l}\text { Subcutaneous skin cells/Rat/IS/2 } \times 10^{6} / \\
\text { Allogeneic/ } 1\end{array}$ & Yes/Yes/Yes & 70 \\
\hline $\begin{array}{l}\text { Takami et al. } \\
\text { (2002) }\end{array}$ & Female/Rat/160-180 & Contusion/T9/Moderate & Sciatic nerve/Rat/IS/2 $\times 10^{6} /$ Allogeneic/7 & $\mathrm{No} / \mathrm{No} / \mathrm{Yes}$ & 70 \\
\hline $\begin{array}{l}\text { Walker et al. } \\
\text { (2015) }\end{array}$ & Female/Rat/200-250 & Contusion/C5/Moderate & Sciatic nerve/Rat/IS/1 × $10^{6} /$ Allogeneic/7 & No/No/Yes & 70 \\
\hline $\begin{array}{l}\text { Wang and } \mathrm{Xu} \\
\text { (2014) }\end{array}$ & Female/Rat/200-220 & Contusion/T9/Moderate & Sciatic nerve/Rat/IS/ $1 \times 10^{6} /$ Allogeneic/7 & Yes/No/Yes & 70 \\
\hline $\begin{array}{l}\text { Yan-Wu et al. } \\
(2011)\end{array}$ & Female/Rat/220-250 & Transection/T9-T10/Severe & MSC/human/IS/1 × $10^{6} /$ Xenogeneic/3 & No/Yes/Yes & 81 \\
\hline $\begin{array}{l}\text { Zaminy et al. } \\
\text { (2013a) }\end{array}$ & Male/Rat/250-300 & Hemisection/T9-T10/Severe & MSC/Rat/IS/1 × 106 /Allogeneic/1 & No/Yes/No & 56 \\
\hline $\begin{array}{l}\text { Zaminy et al. } \\
\text { (2013b) }\end{array}$ & Male/Rat/250-300 & Hemisection/T9-T10/Severe & MSC/Rat/IS/1 × $10^{6} /$ Allogeneic/ 1 & No/Yes/No & 56 \\
\hline Zhang et al. (2007) & Female/Rat/200-250 & Transection/T10/Severe & Sciatic nerve/Rat/IS/1 × $10^{6} /$ Allogeneic/ 1 & No/Yes/Yes & 54 \\
\hline $\begin{array}{l}\text { Zhang et al. } \\
\text { (2010b) }\end{array}$ & Male/Rat/140-160 & Hemisection/T8/Severe & Sciatic nerve/Rat/IS/1.5 × $10^{5} /$ Allogeneic/7 & Yes/No/Yes & 63 \\
\hline $\begin{array}{l}\text { Zhang et al. } \\
\text { (2010a) }\end{array}$ & $\begin{array}{l}\text { Male and Female/Rat/ } \\
140-160\end{array}$ & Hemisection/T8/Severe & Sciatic nerve/Rat/IS/1.5 × 105/Allogeneic/7 & Yes/No/Yes & 63 \\
\hline Zhang et al. (2015) & Female/Rat/200-250 & Contusion/T8-T9/Moderate & Sciatic nerve/Rat/IS/ $1 \times 10^{5} /$ Allogeneic/ 1 & No/Yes/Yes & 54 \\
\hline
\end{tabular}

\footnotetext{
a T: thoracic level; C: cervical level; IS: intra-spinal; IT: intrathecal; IV: intravenous.
} 
et al., 2015; Pourheydar et al., 2012; Schaal et al., 2007; Sharp et al., 2012; Someya et al., 2008; Sparling et al., 2015; Takami et al., 2002; Walker et al., 2015; Wang and Xu, 2014; Yan-Wu et al., 2011; Zaminy et al., 2013a,b; Zhang et al., 2010a,b, 2015, 2007) (Fig. 1). Characteristics of these studies are presented in Table 2. It is worth mentioning that two experiments with separate protocols were extracted from one study (Someya et al., 2008).

Data gathered from 1046 animals, including 517 control subjects and 529 animals in the transplanted group were analyzed. 28 (68.29\%) studies evaluated female animals, 12 (29.27\%) surveys had included male subjects and $1(2.44 \%)$ study assessed both sexes. Rats were included in 39 (95.12\%) studies and 2 (4.88\%) experiments had been conducted on mice. Spinal cord injuries were induced by contusion model in 26 (63.41\%) studies, compression model in $5(12.19 \%)$ surveys, transection model in 4 (9.76\%), and hemisection model in 4 (9.76\%) studies. Severity of injury was moderate in 33 (80.49) studies and it was severe in the remaining 8 (19.51\%) surveys. The mean duration of time between induction of injury and cell transplantation was $6.6 \pm 8.5$ days (ranged from 1 to 56 days). Transplantation was carried out in acute phase in 12 (29.27\%) studies (immediately after injury), in sub-acute phase in 27 (65.85\%) studies (3-9 days), and in chronic phase in only $2(4.88 \%)$ surveys (more than two weeks after the injury). Cells were transplanted through intra-spinal method (intra-lesion) in all the studies except two. Transplant was allogeneic in 38 (92.68\%) studies and xenogeneic in $3(7.32 \%)$ surveys. The number of transplanted cells varied from $4 \times 10^{5}$ to $2.2 \times 10^{7}$ per one kilogram of the animal's body weight.

\subsection{Meta-analysis}

In order to evaluate motor function recovery in the included studies, Basso, Beattie, and Bresnahan score test was used for rats and Basso Mouse Scale was utilized for mice. No publication bias was observed (Coefficient $=0.08 ; 95 \% \mathrm{CI}$ : $-0.34-0.50 \mathrm{p}=0.71$ ) (Fig. 2). Calculation of pooled SMD showed that transplantation of Schwann cells lead to a moderate improvement in motor function recovery (Pooled SMD $=0.85 ;$ 95\%CI: 0.63-1.07; $\mathrm{p}<0.001$; $\mathrm{I} 2=62.4 \%$ ). The results of this section are presented in Fig. 3 .

As can be seen, a moderate heterogeneity was observed between the articles $\left(\mathrm{I}^{2}=62.4 \% ; \mathrm{p}<0.001\right)$ and so subgroup analysis was performed. Table 3 presents the findings of this analysis. The most important sources of heterogeneity were recipient species, injury model, location of injury, Schwann cells derivation origin, intervention phase, graft type, number of transplanted cells, and donor species. Accordingly, the efficacy

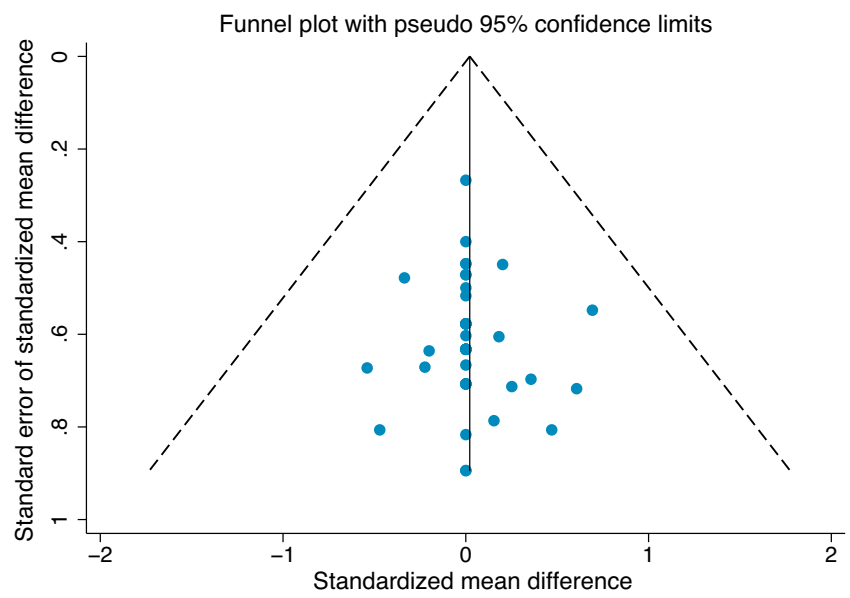

Fig. 2. Funnel plot for assessment of publication bias. of Schwann cell transplantation was found to be relatively higher in compression ( $\mathrm{SMD}=1.04 ; 95 \% \mathrm{CI}$ : 0.58-1.49) and hemisection/ transection ( $\mathrm{SMD}=1.28 ; 95 \% \mathrm{CI}: 0.71-1.85$ ) models compared to the contusion model (SMD $=0.70 ; 95 \% \mathrm{CI}$ : 0.45-0.96). Moreover, application of Schwann cells had better effects in motor function recovery after thoracic injuries $(\mathrm{SMD}=0.88 ; 95 \% \mathrm{CI}$ : 0.64-1.12) compared to injuries of cervical region $(\mathrm{SMD}=0.56$; $95 \% \mathrm{CI}$ : 0.10 1.02). The efficacy of Schwann cell transplantation was also found to be higher when the cells were derived from mesenchymal/skinderived precursors cells ( $\mathrm{SMD}=1.64 ; 95 \% \mathrm{CI}$ : 0.94-2.33), when transplanted in the acute phase (SMD $=1.40 ; 95 \% \mathrm{CI}: 0.97-1.84)$, when the cells are derived from human sources $(\mathrm{SMD}=1.52 ; 95 \%$ CI: 0.55-2.48), and when the observer was not blinded to the treatment groups (SMD $=1.65 ; 95 \% \mathrm{CI}$ : 0.56-2.57).

A meta-regression was performed to evaluate the independent effect of all these variables, in which all the factors were included in a regression model along with their effect size (Table 4). Accordingly, recipient species, donor species, and intervention phase were found to have influenced the efficacy of Schwann cell transplantation in recovery of motor function. The efficacy of these cells was found to be lower in mice $(O R=0.03 ; 0.003-0.41$; $\mathrm{p}=0.009$ ) compared to rats. Schwann cells were found to improve motor function recovery to a greater extent, when the cells were derived from human sources $(\mathrm{OR}=10.96 ; 1.49-80-77 ; \mathrm{p}=0.02)$. Cell therapy in the acute phase $(\mathrm{OR}=4.3 ; 1.53-12.05 ; \mathrm{p}=0.007)$ also showed better results compared to sub-acute $(\mathrm{OR}=1.63 ; 0.63-$ 4.17; $p=0.29$ ) and chronic phases. A significant increase in the efficacy was also observed when mesenchymal/skin-derived precursors Schwann cells were used instead of peripheral nerve derived Schwann cells ( $\mathrm{OR}=2.34 ; 95 \% \mathrm{CI}$ : 1.28-4.29; $\mathrm{p}=0.007)$.

\section{Discussion}

The present meta-analysis showed that transplantation of Schwann cells can induce a moderate motor function recovery after spinal cord injuries. Transplantation of these cells in the acute phase (immediately after injury) causes the efficacy to be twice the time when they are transplanted in the sub-acute of chronic phases $(\mathrm{SMD}=1.40$ vs. 0.67$)$. Application of mesenchymal/skin-derived precursors Schwann cells $(\mathrm{SMD}=1.64$ vs.0.69) and cells with human sources ( $\mathrm{SMD}=1.52$ vs. 0.79 ) also nearly doubled the efficacy of this treatment.

Lu et al. in a similar attempt conducted a meta-analysis in 2015, including 14 animal studies. They declared that Schwann cell transplantation can significantly improve motor function recovery in mice after spinal cord injuries, (Lu et al., 2015) while in the present study, only a moderate improvement was observed. The study conducted by Lu et al. had some important limitations. It was written in Chinese language, the authors only found 176 related non-repetitive articles in their systematic search and they included unrelated keywords for their search which is indicative of a weak search strategy that led to inclusion of only 14 studies in their meta-analysis. This increases the chance of publication bias in their survey. However, in the present study keywords were selected as extended as possible and more databases were searched. A great effort was paid to access gray literatures. This strategy led to screening of 6391 non-repetitive studies. Even after exclusion of surveys that had used co-treatments, 41 studies were included in the meta-analysis. Exclusion of these studies significantly decreased heterogeneity between the included articles $\left(\mathrm{I}^{2}=62.4 \%\right)$ compared to that of Lu's survey $\left(\mathrm{I}^{2}=82.2 \%\right)$. Moreover, no publication bias was observed in the present study. Application of an extended and more precise search strategy led to inclusion of more negative studies in our meta-analysis and so the efficacy of Schwann cells was found to be lower than that of reported by $\mathrm{Lu}$ et al. (Lu et al., 2015). 
Random effects meta-analysis

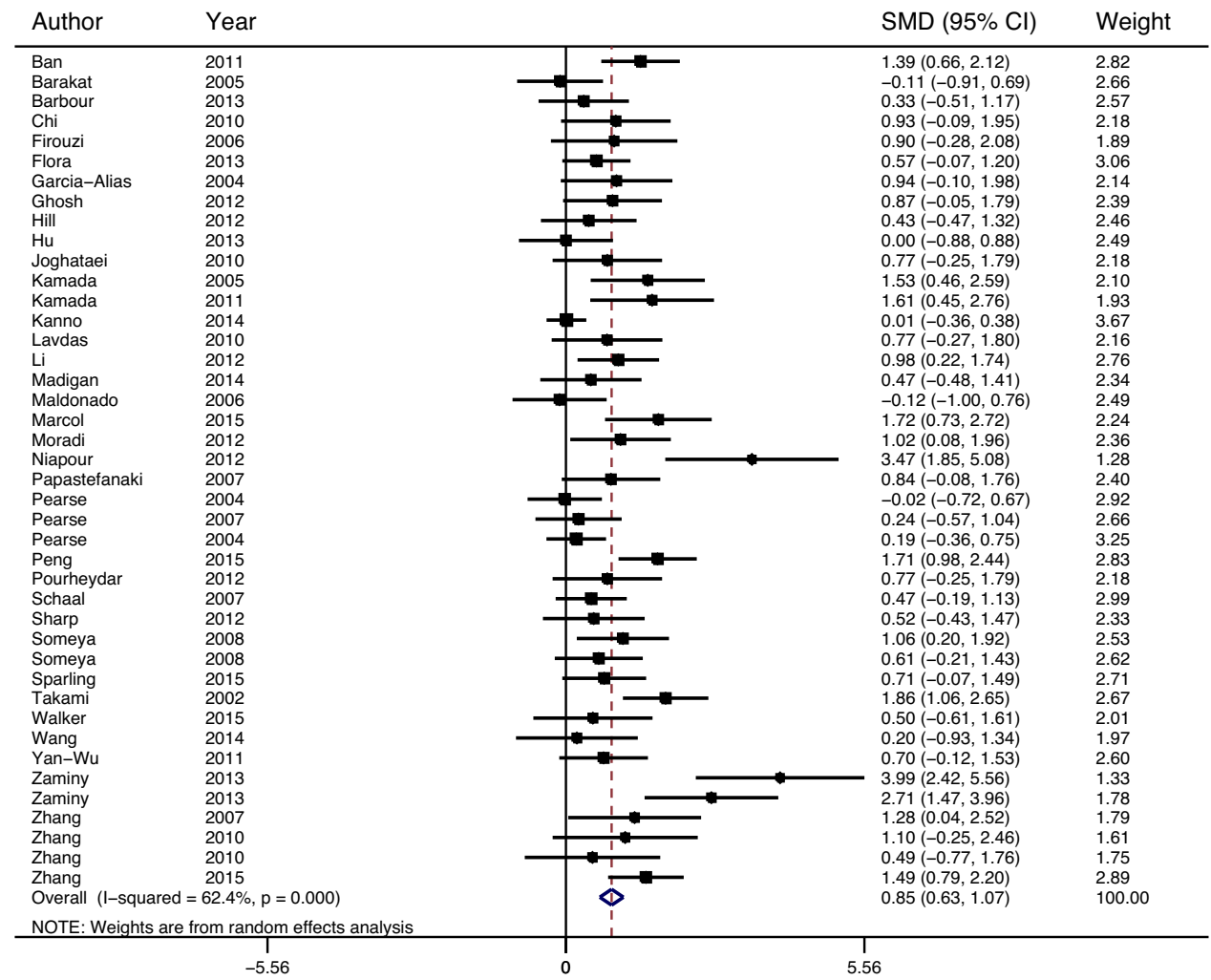

Fig. 3. Efficacy of Schwann cell transplantation on motor function recovery.

Another meta-analysis was done by Yang et al. in 2015. The study showed that Schwann cells have significant beneficial effects in motor recovery in various animal models of spinal cord injury (Yang et al., 2015b). However, there are major differences between the present study and Yang et al. study. The most important difference is in the search strategy of the studies. Searching in only one database in addition to Cochrane library, without searching in gray literature or doing hand search in Yang et al. study resulted in missing a large number of the articles and only 14 articles were evaluated in their meta-analysis. While, using an extensive strategy in the present study led to 41 articles entering the study. This resulted in major differences in the findings of the studies. For instance, Yang et al. study showed that Schwan cells are substantially beneficial regarding motor recovery in widely-used spinal cord injury animal models $(\mathrm{SMD}=1.83)$. In contrast, the findings of the present study showed that improvement of motor function recovery after Schwann cell transplantation is only moderate $(\mathrm{SMD}=0.85)$. In addition, in Yang et al. study some degrees of publication bias is seen ( $P_{\text {forEgger'sTest }}=0.087$ ), while in the present study, no publication bias is observed $\left(\mathrm{P}_{\text {forEgger'sTest }}=\right.$ 0.71 ). Furthermore, the present study showed that there is no difference regarding effectiveness of stem cells between injury models, while Yang et al. study showed that Schwann cells have no effect on improvement of motor recovery in impact (contusion and compression) models, but lead to motor recovery of animals in hemisection model.

The moderate effect of Schwann cell transplantation in motor function recovery after spinal cord injuries could be attributed to the specifications of the injury and innate characteristics of Schwann cells. Although these cells are not found in the central nervous system, after spinal injury, due to inclusion of the dorsal root, Schwann cells migrate to the lesion site and induce myelination and axonal regeneration through their neuro-protective effects (Guest et al., 2005; Nagoshi et al., 2011). However, current evidence shows that during spinal injury, supra-spinal axons rarely regenerate in the site of lesion or at the site of Schwann cell transplantation and even the regenerated axons are not able to establish an effective connection with the spinal tissues (Chau et al., 2004; Golden et al., 2007; Takami et al., 2002). Accordingly, transplantation of Schwann cells at the site of spinal cord injury cannot significantly improve recovery of the motor function and that is why it is suggested by many studies that cotreatments should be used alongside transplantation to improve motor function recovery (Feng et al., 2005; Joghataei et al., 2010; Li et al., 2007; Maldonado et al., 2006; Pourheydar et al., 2012; Xia et al., 2013; Zeng et al., 2005; Zhang et al., 2010a).

Although the overall analysis of this study was indicative of a moderate efficacy, but application of Schwann cell transplantation in the acute phase was associated with doubling of the efficacy. This might be due to the protective role of Schwann cells in prevention and improvement of inflammatory processes. Although the environment around the site of lesion might be cytotoxic during the first hours after injury, presence of Schwann cells can induce release of growth factors which can stimulate the injured neurons for survival or axonal regeneration (Bixby et al., 1988). On the other hand, in sub-acute and chronic phases, the majority of axons are damaged and release of these growth factors cannot induce their effects. The findings of this study are congruent with the results of our previous meta-analysis, in which transplantation of bone marrow-derived mesenchymal cells was shown to exhibit higher efficacy in improvement of neuropathic pains after spinal cord injury when performed in the first 4 days after injury (Hosseini et al., 2015). 
Table 3

Subgroup analyses of the effect of Schwann cell transplantation on motor function recovery.

\begin{tabular}{|c|c|c|c|c|c|}
\hline & P for bias ${ }^{\mathrm{a}}$ & Model & $P\left(I^{2}\right)^{b}$ & $\begin{array}{l}\text { Effect Size }^{\mathrm{c}} \\
(95 \% \mathrm{CI})\end{array}$ & $\mathrm{P}$ \\
\hline \multicolumn{6}{|l|}{ Gender } \\
\hline Male & 0.84 & REM & $0.002(52.0 \%)$ & $0.85(0.63-1.07)$ & $<0.001$ \\
\hline Female & 0.37 & REM & $0.001(60.6 \%)$ & $0.62(0.41-0.85)$ & $<0.001$ \\
\hline Overall significance test among subgroups & & & & & $<0.001$ \\
\hline \multicolumn{6}{|l|}{ Recipient species } \\
\hline Rat & 0.95 & REM & $<0.001(64.2 \%)$ & $0.86(0.63-1.09)$ & $<0.001$ \\
\hline Mice & 0.99 & FEM & $0.92(0.0 \%)$ & $0.81(0.12-1.49)$ & 0.02 \\
\hline Overall significance test among subgroups & & & & & $<0.001$ \\
\hline \multicolumn{6}{|l|}{ Injury model } \\
\hline Contusion & 0.77 & REM & $<0.001(63.8 \%)$ & $0.70(0.45-0.96)$ & $<0.001$ \\
\hline Compression & 0.64 & FEM & $0.67(0.0 \%)$ & $1.04(0.58-1.49)$ & $<0.001$ \\
\hline Hemisection/Transection & 0.35 & FEM & $0.44(0.0 \%)$ & $1.28(0.71-1.85)$ & $<0.001$ \\
\hline Other & 0.99 & FEM & $0.73(0.0 \%)$ & $0.80(0.17-1.42)$ & 0.013 \\
\hline Overall significance test among subgroups & & & & & $<0.001$ \\
\hline \multicolumn{6}{|l|}{ Location of injury } \\
\hline Cervical & 0.91 & FEM & $0.89(0.0 \%)$ & $0.56(0.10-1.02)$ & 0.02 \\
\hline Thoracic & 0.73 & REM & $<0.001(64.9 \%)$ & $0.88(0.64-1.12)$ & $<0.001$ \\
\hline Overall significance test among subgroups & & & & & $<0.001$ \\
\hline \multicolumn{6}{|l|}{ Severity of injury } \\
\hline Moderate & 0.79 & REM & $<0.001(57.6 \%)$ & $0.75(0.53-0.97)$ & $<0.001$ \\
\hline Severe & 0.43 & REM & $<0.001(69.6 \%)$ & $1.44(0.70-2.18)$ & $<0.001$ \\
\hline Overall significance test among subgroups & & & & & $<0.001$ \\
\hline \multicolumn{6}{|l|}{ Schwann cells derivation origin } \\
\hline Sciatic nerve & 0.65 & REM & $0.001(50.4 \%)$ & $0.69(0.48-0.90)$ & $<0.001$ \\
\hline Mesenchymal/skin derived cell & 0.32 & FEM & $<0.001(74.1 \%)$ & $1.64(0.94-2.33)$ & $<0.001$ \\
\hline Overall significance test among subgroups & & & & & $<0.001$ \\
\hline \multicolumn{6}{|l|}{ Intervention phase ${ }^{\mathrm{d}}$} \\
\hline Acute & 0.55 & REM & $0.006(57.9 \%)$ & $1.40(0.97-1.84)$ & $<0.001$ \\
\hline Subacute & 0.75 & REM & $0.001(50.4 \%)$ & $0.67(0.44-0.90)$ & $<0.001$ \\
\hline Chronic & 0.99 & FEM & $0.46(0.0 \%)$ & $0.10(-0.48-0.68)$ & 0.74 \\
\hline Overall significance test among subgroups & & & & & $<0.001$ \\
\hline \multicolumn{6}{|l|}{ Graft type } \\
\hline Allogeneic & 0.79 & REM & $<0.001(64.2 \%)$ & $0.85(0.61-1.09)$ & $<0.001$ \\
\hline Xenogeneic & 0.29 & FEM & $0.46(0.0 \%)$ & $1.02(0.47-1.56)$ & $<0.001$ \\
\hline Overall significance test among subgroups & & & & & $<0.001$ \\
\hline \multicolumn{6}{|l|}{ Number of transplanted cells } \\
\hline$<3 \times 10^{6}$ cell dose $/ \mathrm{kg}$ & 0.16 & FEM & $0.19(22.7 \%)$ & $0.72(0.49-0.95)$ & $<0.001$ \\
\hline$\geq 3 \times 10^{6}$ cell dose $/ \mathrm{kg}$ & 0.39 & REM & $<0.001(72.8 \%)$ & $0.92(0.61-1.24)$ & $<0.001$ \\
\hline Overall significance test among subgroups & & & & & $<0.001$ \\
\hline \multicolumn{6}{|l|}{ Donor species } \\
\hline Rat & 0.94 & REM & $<0.001(63.0 \%)$ & $0.79(0.56-1.03)$ & $<0.001$ \\
\hline Mice & 0.99 & REM & $0.02(68.5 \%)$ & $0.81(0.12-1.49)$ & $<0.001$ \\
\hline Human & 0.41 & FEM & $0.92(0.0 \%)$ & $1.52(0.55-2.48)$ & $<0.001$ \\
\hline Overall significance test among subgroups & & & & & 0.95 \\
\hline \multicolumn{6}{|l|}{ Use of antibiotic } \\
\hline No & 0.11 & REM & $0.06(43.2 \%)$ & $0.78(0.39-1.16)$ & $<0.001$ \\
\hline Yes & 0.85 & REM & $<0.001(67.5 \%)$ & $0.89(0.62-1.16)$ & $<0.001$ \\
\hline Overall significance test among subgroups & & & & & $<0.001$ \\
\hline \multicolumn{6}{|l|}{ Use of immunosuppressive agents } \\
\hline No & 0.97 & REM & $<0.001(50.3 \%)$ & $0.83(0.56-1.10)$ & $<0.001$ \\
\hline Yes & 0.62 & REM & $0.02(66.7 \%)$ & $0.90(0.53-1.28)$ & $<0.001$ \\
\hline Overall significance test among subgroups & & & & & $<0.001$ \\
\hline \multicolumn{6}{|l|}{ Blinding of observer } \\
\hline No & 0.26 & REM & $<0.001(83.1 \%)$ & $1.65(0.56-2.75)$ & 0.003 \\
\hline Yes & 0.78 & REM & $<0.001(52.3 \%)$ & $0.75(0.55-0.96)$ & $<0.001$ \\
\hline Overall significance test among subgroups & & & & & $<0.001$ \\
\hline
\end{tabular}

a Publication bias based on Begg's and Egger's test.

b Heterogeneity among studies.

c Standardized mean difference.

d Acute (immediately after injury), subacut: 3-10 days after injury; chronic: equal or more than 14 days. REM: Random effect model; FEM: Fixed effect, CI: Confidence interval; NA: Not applicable because of low number of included studies. 
Table 4

Meta regression analyses of the effect of Schwann cell transplantation on motor function recovery.

\begin{tabular}{|c|c|c|c|}
\hline Variable & Odds ratio & 95\% Confidence Interval & $\mathrm{P}$ \\
\hline \multicolumn{4}{|l|}{ Gender } \\
\hline Female & Ref & $\operatorname{Ref}$ & --- \\
\hline Male & 1.55 & $0.89-2.70$ & 0.11 \\
\hline \multicolumn{4}{|l|}{ Recipient species } \\
\hline Rat & Ref & Ref & --- \\
\hline Mice & 0.03 & $0.003-0.41$ & 0.009 \\
\hline \multicolumn{4}{|l|}{ Injury model } \\
\hline Contusion & Ref & $\operatorname{Ref}$ & --- \\
\hline Compression & 1.07 & $0.45-2.56$ & 0.86 \\
\hline Hemisection/Transection & 0.37 & $0.11-1.25$ & 0.11 \\
\hline Other & 0.92 & $0.12-3.34$ & 0.22 \\
\hline \multicolumn{4}{|l|}{ Severity of Injury } \\
\hline Moderate & Ref & Ref & --- \\
\hline Severe & 2.07 & $0.66-6.58$ & 0.21 \\
\hline \multicolumn{4}{|l|}{ Location of injury } \\
\hline Thoracic & Ref & $\operatorname{Ref}$ & --- \\
\hline Cervical & 0.84 & $0.39-1.81$ & 0.65 \\
\hline \multicolumn{4}{|l|}{ Stem cells derivation origin } \\
\hline Sciatic & Ref & Ref & --- \\
\hline Mesenchymal/skin derived cell & 2.34 & $1.28-4.29$ & 0.008 \\
\hline \multicolumn{4}{|l|}{ Donor species } \\
\hline Rat & $\operatorname{Ref}$ & Ref & --- \\
\hline Human & 10.96 & $1.49-80.77$ & 0.02 \\
\hline \multicolumn{4}{|l|}{ Intervention phase ${ }^{a}$} \\
\hline Chronic & Ref & $\operatorname{Ref}$ & --- \\
\hline Subacute & 1.63 & $0.63-4.17$ & 0.29 \\
\hline Acute & 4.30 & $1.53-12.05$ & 0.007 \\
\hline \multicolumn{4}{|l|}{ Graft type } \\
\hline Allogeneic & Ref & $\operatorname{Ref}$ & --- \\
\hline Xenogeneic & 0.54 & $0.01-1.09$ & 0.06 \\
\hline \multicolumn{4}{|l|}{ Number of transplanted cells } \\
\hline$<3 \times 10^{6}$ cell dose $/ \mathrm{kg}$ & Ref & Ref & --- \\
\hline$\geq 3 \times 10^{6}$ cell dose $/ \mathrm{kg}$ & 1.20 & $0.68-2.1$ & 0.52 \\
\hline \multicolumn{4}{|c|}{ Use of immunosuppressive agents } \\
\hline No & Ref & $\operatorname{Ref}$ & --- \\
\hline Yes & 0.78 & $0.46-1.33$ & 0.34 \\
\hline \multicolumn{4}{|l|}{ Use of antibiotic } \\
\hline No & Ref & Ref & --- \\
\hline Yes & 0.77 & $0.46-1.32$ & 0.33 \\
\hline \multicolumn{4}{|l|}{ Blinding of observer } \\
\hline No & $\operatorname{Ref}$ & $\operatorname{Ref}$ & --- \\
\hline Yes & 0.79 & $0.36-1.76$ & 0.56 \\
\hline
\end{tabular}

a Acute (immediately after injury), subacut: 3-10 days after injury; chronic: equal or more than 14 days. Ref: Reference category.

The most common method for extraction and culture of Schwann cells is using peripheral nerves; however, recently some studies have used other sources including mesenchymal/skinderived precursor Schwann cells. In these surveys, after differentiation to Schwann cells, they are transplanted at the site of spinal cord injury (Bunge, 2008; Kamada et al., 2011, 2005; Niapour et al., 2012; Someya et al., 2008; Yan-Wu et al., 2011; Zaminy et al., 2013a, 2013b). Subgroup analysis in the present study showed that in comparison with earlier derivation methods (from peripheral neurons), transplantation of mesenchymal/skin derived Schwann cells is associated with an increase in the recovery of motor function. This could be attributed to the modulation of inflammatory/immune responses by mesenchymal cells, since transplanted Schwann cells might be at different levels of differentiation and some might have preserved characteristics of mesenchymal cells (Urdzíková et al., 2014; Watanabe et al., 2015). Moreover, skinderived Schwann cells are better at migration to the injured site and establishment of effective synaptic connections compared to peripheral nerves. These cells can modify the adjacent host tissue which can decrease gliosis (Biernaskie et al., 2007).

Application of human Schwann cells was another factor that increased efficacy of this treatment in motor function recovery. In four studies included in the meta-analysis, Schwann cells had human sources (Kamada et al., 2011; Moradi et al., 2012; Niapour et al., 2012; Yan-Wu et al., 2011), in three of which the Schwann cells were derived from mesenchymal stem cells (Kamada et al., 2011; Niapour et al., 2012; Yan-Wu et al., 2011). Therefore, the greater efficacy of human-derived cells might be caused by the anti-inflammatory and protective effects of mesenchymal cells rather than the Schwann cells (Singer and Caplan, 2011). Mesenchymal cells exhibit immunomodulatory effects (Alunno et al., 2014; Coulson-Thomas et al., 2014; Hou et al., 2014; Menendez et al., 2014; Montespan et al., 2014; Nauta and Fibbe, 2007; Wang et al., 2009) and when transplanted at a suitable time, they can minimize the inflammatory processes and damages caused by the immune system (Oudega and Ritfeld, 2014). Transplantation of these cells can decrease proliferation of glial cells and improve recovery by biologically active molecules through regulating release of cytokines and growth factors. Furthermore, their role in vascularization might induce generation of new vasculature in the spine (Hua et al., 2014; Kuchroo et al., 2014).

The results of the present study were also indicative of interspecies differences and efficacy of Schwann cell transplantation was found to be lower in mice, compared to rats $(\mathrm{OR}=0.03)$. Although mice were only included in two studies, the differences cannot be ignored. The Lu et al. (Lu et al., 2015) and Yang et al. studies did not assess the inter-species differences of Schwann cell efficacy on motor function recovery after SCI. Therefore, comparison is not possible. Nevertheless, similar findings were also observed in our previous meta-analysis (Hosseini et al., 2015). Further investigations are required to confirm or reject the interspecies differences regarding treatment response to Schwann cell transplantation. If an inter-species difference exists regarding effectiveness of Schwann cells, more caution should be taken regarding using these cells in clinical trials. Therefore, it is suggested to evaluate the role of inter-species differences in effectiveness of Schwann cell transplantation in spinal cord injury recovery before carrying out any clinical trials.

The nature of this meta-analysis can be pointed out as one of the most important limitations of this survey. Due to their innate limitation in evaluating all the confounding factors, behavioral studies cannot definitely prove causal relationships. Although we tried our best to include studies with similar methodologies and controlling methods for confounding factors, but even in ideal situations these objectives cannot be reached. The presence of moderate heterogeneity was another limitation of this study which led the meta-analysis to be designed based on random effect model. In order to overcome this issue, subgroup analysis was performed which eliminated heterogeneity in 8 cases (Table 3 ).

\section{Conclusion}

Efficacy of Schwann cell transplantation in spinal cord injuries is evaluated in several studies, the results of which are somewhat incongruent. In this regard, we aimed to pool all these results in order to reach a consensus through a meta-analytic approach. The findings of this meta-analysis showed that transplantation of Schwann cells can moderately improve motor function recovery. 
Finally it seems that inter-species differences might exist regarding the efficacy of this treatment protocol.

\section{Conflict of interest statement}

The authors report no declarations of interest.

\section{Author contributions}

All authors passed four criteria for authorship contribution based on recommendations of the International Committee of Medical Journal Editors.

\section{Acknowledgements}

This research has been supported by a Tehran University of Medical Sciences and Health Services grant and Sina Trauma and Surgery research center, Tehran University of Medical Sciences grant (grant number: 94-03-38-29982).

\section{References}

Alunno, A., Montanucci, P., Bistoni, O., Basta, G., Caterbi, S., Pescara, T., Pennoni, I., Bini, V., Bartoloni, E., Gerli, R., 2014. In vitro immunomodulatory effects of microencapsulated umbilical cord Wharton jelly-derived mesenchymal stem cells in primary Sjögren's syndrome. Rheumatology (Oxford) 54, 163-168.

Antonic, A., Sena, E.S., Lees, J.S., Wills, T.E., Skeers, P., Batchelor, P.E., Macleod, M.R. Howells, D.W., 2013. Stem cell transplantation in traumatic spinal cord injury: a systematic review and meta-analysis of animal studies. PLoS Biol. 11, e1001738.

Ban, D.X., Ning, G.Z., Feng, S.Q., Wang, Y., Zhou, X.H., Liu, Y., Chen, J.T., 2011. Combination of activated Schwann cells with bone mesenchymal stem cells: the best cell strategy for repair after spinal cord injury in rats. Regenr. Med. 6, 707720.

Barakat, D.J., Gaglani, S.M., Neravetla, S.R., Sanchez, A.R., Andrade, C.M., Pressman, Y., Puzis, R., Garg, M.S., Bunge, M.B., Pearse, D.D., 2005. Survival, integration, and axon growth support of glia transplanted into the chronically contused spinal cord. Cell Transplant. 14, 225-240.

Barbour, H.R., Plant, C.D., Harvey, A.R., Plant, G.W., 2013. Tissue sparing, behavioral recovery, supraspinal axonal sparing/regeneration following sub-acute glial transplantation in a model of spinal cord contusion. BMC Neurosci. 14, 106.

Biernaskie, J., Sparling, J.S., Liu, J., Shannon, C.P., Plemel, J.R., Xie, Y., Miller, F.D., Tetzlaff, W., 2007. Skin-derived precursors generate myelinating Schwann cells that promote remyelination and functional recovery after contusion spinal cord injury. J. Neurosci. 27, 9545-9559.

Bixby, J.L., Lilien, J., Reichardt, L.F., 1988. Identification of the major proteins that promote neuronal process outgrowth on Schwann cells in vitro. J. Cell Biol. 107, 353-361.

Bunge, M.B., 2008. Novel combination strategies to repair the injured mammalian spinal cord. J. Spinal Cord Med. 31, 262-269.

Chau, C.H., Shum, D.K., Li, H., Pei, J., Lui, Y.Y., Wirthlin, L., Chan, Y.S., Xu, X.M., 2004. Chondroitinase ABC enhances axonal regrowth through Schwann cell-seeded guidance channels after spinal cord injury. FASEB J. 18, 194-196.

Coulson-Thomas, V.J., Gesteira, T.F., Hascall, V., Kao, W., 2014. Umbilical cord mesenchymal stem cells suppress host rejection: the role of the glycocalyx. J. Biol. Chem. 289, 23465-23481.

Egger, M., Smith, G.D., Schneider, M., Minder, C., 1997. Bias in meta-analysis detected by a simple, graphical test. BMJ 315, 629-634.

Feng, S.Q., Kong, X.H., Guo, S.F., Wang, P., Li, L., Zhong, J.H., Zhou, X.F., 2005 Treatment of spinal cord injury with co-grafts of genetically modified Schwann cells and fetal spinal cord cell suspension in the rat. Neurotox. Res. 7, 169-177.

Firouzi, M., Moshayedi, P., Saberi, H., Mobasheri, H., Abolhassani, F., Jahanzad, I., Raza, M., 2006. Transplantation of Schwann cells to subarachnoid space induces repair in contused rat spinal cord. Neurosci. Lett. 402, 66-70.

Flora, G., Joseph, G., Patel, S., Singh, A., Bleicher, D., Barakat, D.J., Louro, J., Fenton, S., Garg, M., Bunge, M.B., Pearse, D.D., 2013. Combining neurotrophin-transduced schwann cells and rolipram to promote functional recovery from subacute spinal cord injury. Cell Transplant. 22, 2203-2217.

Garcia-Alias, G., Lopez-Vales, R., Fores, J., Navarro, X., Verdu, E., 2004. Acute transplantation of olfactory ensheathing cells or Schwann cells promotes recovery after spinal cord injury in the rat. J. Neurosci. Res. 75, 632-641.

Ghosh, M., Jahrling, N., Henao, M.C., Dodt, H.U., Pearse, D.D., 2012. The utility of 3D ultramicroscopy for evaluating cellular therapies after spinal cord injury. Top. Spinal Cord Inj. Rehabil. 18, 73-76.

Golden, K.L., Pearse, D.D., Blits, B., Garg, M.S., Oudega, M., Wood, P.M., Bunge, M.B., 2007. Transduced Schwann cells promote axon growth and myelination after spinal cord injury. Exp. Neurol. 207, 203-217.

Guest, J.D., Hiester, E.D., Bunge, R.P., 2005. Demyelination and Schwann cell responses adjacent to injury epicenter cavities following chronic human spinal cord injury. Exp. Neurol. 192, 384-393.
Hill, C.E., Brodak, D.M., Bartlett Bunge, M., 2012. Dissociated predegenerated peripheral nerve transplants for spinal cord injury repair: a comprehensive assessment of their effects on regeneration and functional recovery compared to Schwann cell transplants. J. Neurotrauma 29, 2226-2243.

Hosseini, M., Yousefifard, M., Aziznejad, H., Nasirinezhad, F., 2015. The effect of bone marrow-derived mesenchymal stem cell transplantation on allodynia and hyperalgesia in neuropathic animals: a systematic review with meta-analysis. Biol. Blood Marrow Transplant. 21, 1537-1544.

Hou, R., Liu, R., Niu, X., Chang, W., Yan, X., Wang, C., Li, J., An, P., Li, X., Yin, G., 2014. Biological characteristics and gene expression pattern of bone marrow mesenchymal stem cells in patients with psoriasis. Exp. Dermatol. 23, 521-523.

Hu, J.G., Wang, X.F., Deng, L.X., Liu, N.K., Gao, X., Chen, J.H., Zhou, F.C., Xu, X.M., 2013. Cotransplantation of glial restricted precursor cells and Schwann cells promotes functional recovery after spinal cord injury. Cell Transplant. 22, 2219-2236.

Hua, J., He, Z.-G., Qian, D.-H., Lin, S.-P., Gong, J., Meng, H.-B., Yang, T.-S., Sun, W., Xu, B., Zhou, B., 2014. Angiopoietin-1 gene-modified human mesenchymal stem cells promote angiogenesis and reduce acute pancreatitis in rats. Int. J. Clin. Exp. Pathol. 7, 3580.

Joghataei, M.T., Bakhtiari, M., Pourheydar, B., Mehdizadeh, M., Faghihi, A., Mehraein F., Behnam, B., Pirhajati, V., 2010. Co-transplantation of Schwann and bone marrow stromal cells promotes locomotor recovery in the rat contusion model of spinal cord injury. Cell J. 12, 7-16.

Kamada, T., Koda, M., Dezawa, M., Yoshinaga, K., Hashimoto, M., Koshizuka, S., Nishio, Y., Moriya, H., Yamazaki, M., 2005. Transplantation of bone marrow stromal cell-derived Schwann cells promotes axonal regeneration and functional recovery after complete transection of adult rat spinal cord. J. Neuropathol. Exp. Neurol. 64, 37-45.

Kamada, T., Koda, M., Dezawa, M., Anahara, R., Toyama, Y., Yoshinaga, K., Hashimoto, M., Koshizuka, S., Nishio, Y., Mannoji, C., Okawa, A., Yamazaki, M., 2011. Transplantation of human bone marrow stromal cell-derived Schwann cells reduces cystic cavity and promotes functional recovery after contusion injury of adult rat spinal cord. Neuropathology 31, 48-58.

Kanno, H., Pressman, Y., Moody, A., Berg, R., Muir, E.M., Rogers, J.H., Ozawa, H., Itoi, E., Pearse, D.D., Bunge, M.B., 2014. Combination of engineered Schwann cell grafts to secrete neurotrophin and chondroitinase promotes axonal regeneration and locomotion after spinal cord injury. J. Neurosci. 34, 1838-1855.

Kuchroo, P., Dave, V., Vijayan, A., Viswanathan, C., Ghosh, D., 2014. Paracrine factors secreted by umbilical cord-derived MSCs induce angiogenesis in vitro by a VEGF-independent pathway. Stem Cell Dev. 24, 437-450.

Lavdas, A.A., Chen, J., Papastefanaki, F., Chen, S., Schachner, M., Matsas, R., Thomaidou, D., 2010. Schwann cells engineered to express the cell adhesion molecule L1 accelerate myelination and motor recovery after spinal cord injury. Exp. Neurol. 221, 206-216.

Li, J., Sun, C.R., Zhang, H., Tsang, K.S., Li, J.H., Zhang, S.D., An, Y.H., 2007. Induction of functional recovery by co-transplantation of neural stem cells and schwann cells in a rat spinal cord contusion injury model. Biomed. Environ. Sci. 20, 242 249.

Li, B.C., Xu, C., Zhang, J.Y., Li, Y., Duan, Z.X., 2012. Differing Schwann cells and olfactory ensheathing cells behaviors, from interacting with astrocyte, produce similar improvements in contused rat spinal cord's motor function. J. Mol. Neurosci. 48, 35-44.

Lu, T., Liu, C., Dong, J., Lu, M., Kang, J., He, X.J., 2015. Effect of schwann cells transplantation in the treatment of traumatic spinal-cord injury in rats: a metaanalysis. Chin. J. Evid. Based Med. 15, 705-712.

Madigan, N.N., Chen, B.K., Knight, A.M., Rooney, G.E., Sweeney, E., Kinnavane, L., Yaszemski, M.J., Dockery, P., O'Brien, T., McMahon, S.S., Windebank, A.J., 2014. Comparison of cellular architecture, axonal growth, and blood vessel formation through cell-loaded polymer scaffolds in the transected rat spinal cord. Tissue Eng. 20, 2985-2997.

Maldonado, A., Voda, J., Castro, A., Sagen, J., 2006. Improved functional recovery in the rat contusion model of spinal cord injury using co-grafts of bovine chromaffin and Schwann cells. Exp. Neurol. 198, 580.

Marcol, W., Slusarczyk, W., Larysz-Brysz, M., Francuz, T., Jedrzejowska-Szypulka, H., Labuzek, K., Lewin-Kowalik, J., 2015. Grafted activated schwann cells support survival of injured rat spinal cord white matter. World Neurosurg. 84, 511-519.

Menendez, P., Rodriguez, R., Delgado, M., Rosu-Myles, M., 2014. Human bone marrow mesenchymal stem cells lose immunosuppressive and antiinflammatory properties upon oncogenic transformation. Exp. Hematol. 42, S49.

Moher, D., Liberati, A., Tetzlaff, J., Altman, D.G., 2009. Preferred reporting items for systematic reviews and meta-analyses: the PRISMA statement. Ann. Intern. Med. 151, 264-269.

Montespan, F., Deschaseaux, F., Sensébé, L., Carosella, E.D., Rouas-Freiss, N., 2014. Osteodifferentiated mesenchymal stem cells from bone marrow and adipose tissue express HLA-G and display immunomodulatory properties in HLAmismatched settings: implications in bone repair therapy. J Immunol. Res. 2014, $1-10$.

Moradi, F., Bahktiari, M., Joghataei, M.T., Nobakht, M., Soleimani, M., Hasanzadeh, G., Fallah, A., Zarbakhsh, S., Hejazian, L.B., Shirmohammadi, M., Maleki, F., 2012. BD PuraMatrix peptide hydrogel as a culture system for human fetal Schwann cells in spinal cord regeneration. J. Neurosci. Res. 90, 2335-2348.

Nagoshi, N., Shibata, S., Hamanoue, M., Mabuchi, Y., Matsuzaki, Y., Toyama, Y., Nakamura, M., Okano, H., 2011. Schwann cell plasticity after spinal cord injury shown by neural crest lineage tracing. Glia 59, 771-784.

Nauta, A.J., Fibbe, W.E., 2007. Immunomodulatory properties of mesenchymal stromal cells. Blood 110, 3499-3506. 
Niapour, A., Karamali, F., Nemati, S., Taghipour, Z., Mardani, M., Nasr-Esfahani, M.H. Baharvand, H., 2012. Cotransplantation of human embryonic stem cell-derived neural progenitors and schwann cells in a rat spinal cord contusion injury model elicits a distinct neurogenesis and functional recovery. Cell Transplant. $21,827-843$.

Oudega, M., Ritfeld, G., 2014. Bone marrow-derived mesenchymal stem cell transplant survival in the injured rodent spinal cord. J. Bone Marrow Res. 2, 2-9.

Papastefanaki, F., Chen, J., Lavdas, A.A., Thomaidou, D., Schachner, M., Matsas, R., 2007. Grafts of Schwann cells engineered to express PSA-NCAM promote functional recovery after spinal cord injury. Brain 130, 2159-2174.

Pearse, D.D., Marcillo, A.E., Oudega, M., Lynch, M.P., Wood, P.M., Bunge, M.B., 2004a Transplantation of Schwann cells and olfactory ensheathing glia after spinal cord injury: does pretreatment with methylprednisolone and interleukin-10 enhance recovery. J. Neurotrauma 21, 1223-1239.

Pearse, D.D., Pereira, F.C., Marcillo, A.E., Bates, M.L., Berrocal, Y.A., Filbin, M.T., Bunge, M.B., 2004b. cAMP and Schwann cells promote axonal growth and functional recovery after spinal cord injury. Nat. Med. 10, 610-616.

Pearse, D.D., Sanchez, A.R., Pereira, F.C., Andrade, C.M., Puzis, R., Pressman, Y. Golden, K., Kitay, B.M., Blits, B., Wood, P.M., Bunge, M.B., 2007. Transplantation of Schwann cells and/or olfactory ensheathing glia into the contused spinal cord: survival, migration, axon association, and functional recovery. Glia 55, 976-1000.

Peng, C.G., Zhang, S.Q., Wu, M.F., Lv, Y., Wu, D.K., Yang, Q., Gu, R., 2015. Hyperbaric oxygen therapy combined with schwann cell transplantation promotes spinal cord injury recovery. Neural Regen. Res. 10, 1477-1482.

Pourheydar, B., Joghataei, M.T., Bakhtiari, M., Mehdizadeh, M., Yekta, Z., Najafzadeh, N., 2012. Co- transplantation of bone marrow stromal cells with schwann cells evokes mechanical allodynia in the contusion model of spinal cord injury in rats. Cell J. 13, 213-222.

Schaal, S.M., Kitay, B.M., Cho, K.S., Lo Jr., T.P., Barakat, D.J., Marcillo, A.E., Sanchez, A R., Andrade, C.M., Pearse, D.D., 2007. Schwann cell transplantation improves reticulospinal axon growth and forelimb strength after severe cervical spinal cord contusion. Cell Transplant. 16, 207-228.

Sharp, K.G., Flanagan, L.A., Yee, K.M., Steward, O., 2012. A re-assessment of a combinatorial treatment involving Schwann cell transplants and elevation of cyclic AMP on recovery of motor function following thoracic spinal cord injury in rats. Exp. Neurol. 233, 625-644.

Singer, N.G., Caplan, A.I., 2011. Mesenchymal stem cells: mechanisms of inflammation. Annu. Rev. Pathol. 6, 457-478.

Sistrom, C.L., Mergo, P.J., 2000. A simple method for obtaining original data from published graphs and plots. Am. J. Roentgenol. 174, 1241-1244.

Someya, Y., Koda, M., Dezawa, M., Kadota, T., Hashimoto, M., Kamada, T., Nishio, Y. Kadota, R., Mannoji, C., Miyashita, T., Okawa, A., Yoshinaga, K., Yamazaki, M., 2008. Reduction of cystic cavity, promotion of axonal regeneration and sparing, and functional recovery with transplanted bone marrow stromal cell-derived Schwann cells after contusion injury to the adult rat spinal cord. J. Neurosurg. Spine 9, 600-610.

Sparling, J.S., Bretzner, F., Biernaskie, J., Assinck, P., Jiang, Y., Arisato, H., Plunet, W.T. Borisoff, J., Liu, J., Miller, F.D., Tetzlaff, W., 2015. Schwann cells generated from neonatal skin-derived precursors or neonatal peripheral nerve improve functional recovery after acute transplantation into the partially injured cervical spinal cord of the rat. J. Neurosci. 35, 6714-6730.

Takami, T, Oudega, M., Bates, M.L., Wood, P.M., Kleitman, N., Bunge, M.B., 2002 Schwann cell but not olfactory ensheathing glia transplants improve hindlimb locomotor performance in the moderately contused adult rat thoracic spinal cord. J. Neurosci. 22, 6670-6681.

Urdzíková, L.M., Rǔžička, J., LaBagnara, M., Kárová, K., Kubinová, Š., Jiráková, K., Murali, R., Syková, E., Jhanwar-Uniyal, M., Jendelová, P., 2014. Human mesenchymal stem cells modulate inflammatory cytokines after spinal cord injury in rat. Int. J. Mol. Sci. 15, 11275-11293.

Walker, C.L., Wang, X., Bullis, C., Liu, N.K., Lu, Q., Fry, C., Deng, L., Xu, X.M., 2015. Biphasic bisperoxovanadium administration and Schwann cell transplantation for repair after cervical contusive spinal cord injury. Exp. Neurol. 264, 163-172.

Wang, X., Xu, X.M., 2014. Long-term survival, axonal growth-promotion, and myelination of Schwann cells grafted into contused spinal cord in adult rats. Exp. Neurol. 261, 308-319.

Wang, M., Yang, Y., Yang, D., Luo, F., Liang, W., Guo, S., Xu, J., 2009. The immunomodulatory activity of human umbilical cord blood-derived mesenchymal stem cells in vitro. Immunology 126, 220-232.

Watanabe, S., Uchida, K., Nakajima, H., Matsuo, H., Sugita, D., Yoshida, A., Honjoh, K., Johnson, W.E.B., Baba, H., 2015. Early transplantation of mesenchymal stem cells after spinal cord injury relieves pain hypersensitivity through suppression of pain-related signaling cascades and reduced inflammatory cell recruitment. Stem Cells 33, 1902-1914.

Xia, L., Wan, H., Hao, S.Y., Li, D.Z., Chen, G., Gao, C.C., Li, J.H., Yang, F., Wang, S.G., Liu, S., 2013. Co-transplantation of neural stem cells and Schwann cells within poly (L-lactic-co-glycolic acid) scaffolds facilitates axonal regeneration in hemisected rat spinal cord. Chin. Med. J. (Engl.) 126, 909-917.

Yan-Wu, G., Yi-Quan, K., Ming, L., Ying-Qian, C., Xiao-Dan, J., Shi-Zhong, Z., WangMing, Z., Chuan-Zhi, D., 2011. Human umbilical cord-derived Schwann-like cell transplantation combined with neurotrophin-3 administration in dyskinesia of rats with spinal cord injury. Neurochem. Res. 36, 783-792.

Yang, L., Ge, Y., Tang J., Yuan, J. Ge, D., Chen, H., Zhang, H., Cao, X., 2015a. Schwann cells transplantation improves locomotor recovery in rat models with spinal cord injury: a systematic review and meta-analysis. Cell. Physiol. Biochem. 37, 2171-2182.

Yang, L., Ge, Y., Tang, J., Yuan, J., Ge, D., Chen, H., Zhang, H., Cao, X., 2015b. Schwann cells transplantation improves locomotor recovery in rat models with spinal cord injury: a systematic review and meta-analysis. Cell. Physiol. Biochem. 37, 2171-2182.

Zaminy, A., Shokrgozar, M.A., Sadeghi, Y., Noroozian, M., Heidari, M.H., Piryaei, A., 2013a. Mesenchymal stem cells as an alternative for Schwann cells in rat spinal cord injury. Iran. Biomed. J. 17, 113-122.

Zaminy, A., Shokrgozar, M.A., Sadeghi, Y., Norouzian, M., Heidari, M.H., Piryaei, A., 2013b. Transplantation of schwann cells differentiated from adipose stem cells improves functional recovery in rat spinal cord injury. Arch. Iran. Med. 16, 533541.

Zeng, Y.S., Ding, Y., Wu, L.Z., Guo, J.S., Li, H.B., Wong, W.M., Wu, W.T., 2005. Cotransplantation of schwann cells promotes the survival and differentiation of neural stem cells transplanted into the injured spinal cord. Dev. Neurosci. 27, $20-26$.

Zhang, X., Zeng, Y., Zhang, W., Wang, J., Wu, J., Li, J., 2007. Co-transplantation of neural stem cells and NT-3-overexpressing Schwann cells in transected spinal cord. J. Neurotrauma 24, 1863-1877.

Zhang, J., Wu, G., Zhao, F., Jin, X., 2010a. Co-transplantation of Schwann cells and bone marrow stromal cells versus single cell transplantation on repairing hemisected spinal cord injury of rats. Neural Regener. Res. 5, 805-813.

Zhang, J., Zhao, F., Wu, G., Li, Y., Jin, X., 2010b. Functional and histological improvement of the injured spinal cord following transplantation of Schwann cells transfected with NRG1 gene. Anat. Rec. (Hoboken, N. J.: 2007) 293, 19331946.

Zhang, S.Q., Wu, M.F., Piao, Z., Yao, J., Li, J.H., Wang, X.G., Liu, J., 2015. Edaravone combined with Schwann cell transplantation may repair spinal cord injury in rats. Neural Regener. Res. 10, 230-236. 